\title{
Presença negra no material didático de História adotado pelo Estado de São Paulo: 2014-2017
}

\author{
Neide Cristina da Silva ${ }^{1}$
}

\section{RESUMO}

A presente pesquisa tem como objeto a análise dos efeitos da aplicação da Lei n. ${ }^{\circ}$ 10.639/03 nos livros didáticos de História para o Ensino Médio. Pretendeu-se verificar se os componentes históricos das matrizes curriculares carregados de denotações ou de conotações racistas foram reformulados, alterados ou até mesmo banidos após a implantação da referida lei. O problema central é que, apesar da mudança nos conteúdos curriculares, a História do Brasil continua a ser narrada com a imposição da visão de mundo da classe dominante. Para a realização desta pesquisa foram trabalhadas, como categorias principais, conscientização/alienação e colonialidade/racialidade tendo como aportes teóricos Paulo Freire e Aníbal Quijano. A análise demonstrou que apesar dos avanços no ensino de história e cultura afro-brasileira, a partir da promulgação da Lei $n{ }^{\circ}{ }^{\circ}$ 10.639/03, a racialidade do saber, presente na historiografia didática, não permite superar a perspectiva temporal da história que situa o negro como inferior.

PALAVRAS-CHAVE: Material didático. História. Racionalidade. Povo negro. Lei n. ${ }^{\circ}$ 10.639/03.

Black presence in the didactic material of History adopted by the

State of São Paulo: 2014-2017

\footnotetext{
${ }^{1}$ Doutora em Educação. UNIDRUMMOND; UNINOVE. São Paulo, SP, Brasil. neidesilva87@hotmail.com
} 


\begin{abstract}
The present research aims to analyze the effects of the application of the Law 10.639/03 in textbooks of History for High School. The aim was to verify if the historical components of the curricular matrices loaded with denotations or racist connotations were reformulated, altered or even banned after the implementation of the said law. The central problem is that, despite the change in curricular content, the History of Brazil continues to be narrated with the imposition of the worldview of the ruling class. For the accomplishment of this research were worked, like main categories, awareness / alienation and coloniality / raciality having as theoretical contributions Paulo Freire and Aníbal Quijano. The analysis showed that despite the advances in the teaching of Afro-Brazilian history and culture, since the promulgation of the law 10.639/03, the raciality of knowledge, present in didactic historiography, does not allow to overcome the temporal perspective of the history that situates the black people as inferior.
\end{abstract}

KEY WORDS: Didactic material. History. Rationality. Black people. Law No. 10.639 / 03.

\title{
Introdução
}

A educação é dever da família e do Estado e tem por principal objetivo o pleno desenvolvimento do educando. O sistema educacional brasileiro é dividido em educação básica e ensino superior. A presente pesquisa tem como objeto a análise do material didático destinado à educação básica, portanto, não abarcará reflexões acerca do ensino superior.

De acordo com o artigo $4 .^{\circ}$, inciso VIII, da Lei 9.394/96 (Lei de Diretrizes e Bases da Educação Nacional - LDB), o dever do Estado com educação escolar pública será efetivado mediante a garantia de atendimento ao educando, em todas as etapas da educação básica, por meio de programas suplementares de material didático-escolar, transporte, alimentação e assistência à saúde. 
Tendo como base essa diretriz, o governo do Estado de São Paulo, em parceira com o Programa Nacional do Livro Didático (PNLD), realiza anualmente, por meio de professores e gestores das escolas públicas, a escolha dos livros didáticos que serão utilizados nos anos subsequentes. Os livros são utilizados por três anos e as escolhas ocorrem alternadamente (do $1 .^{\circ}$ ao $5 .^{\circ}$ ano do Ensino Fundamental, do $6 .^{\circ}$ ao $9 .^{\circ}$ ano do mesmo ensino e das três séries do Ensino Médio). No ano de 2014, houve a escolha dos livros didáticos da 1. ${ }^{\mathrm{a}}, 2$. $^{\mathrm{a}}$ e 3. ${ }^{\mathrm{a}}$ série do Ensino Médio, que foram adotados em 2015 e utilizados até 2017, quando ocorreu uma nova escolha.

Considerando que os livros didáticos são grandes aliados dos dominadores, na medida em que, salvo exceções, contam a história do povo brasileiro a partir da chegada do colonizador "branco", é necessário saber a favor de quem está o ensino e os materiais didáticos.

Nesta pesquisa, os livros didáticos analisados constituem uma das coleções selecionadas pelos(as) professores(as) do Estado de São Paulo no ano de 2014. São três volumes do livro História Global: Brasil e Geral, da editora Saraiva, de autoria de Cotrim (2013), que apresenta o manual do professor como anexo de cada volume. Também serão objeto de análise os Cadernos do professor e do aluno da Secretaria Estadual de Ensino, destinados ao ensino médio na disciplina de História.

Para a análise destes materiais didáticos, partiu-se da premissa que a História do Brasil deve ser contada com a inclusão das vozes silenciadas dos negros, ameríndios e marginalizados da sociedade, a partir da visão de mundo dos "vencidos", desconstruindo estereótipos do(a) negro(a) como escravizado(a) subalterno(a) e resignado(a); ameríndios(as) como um único povo "índio", retratado como no período da primeira invasão portuguesa e os marginalizados, como bandidos e miseráveis, tanto na América Latina como no continente Africano.

Em virtude dessa posição optou-se considerar a periodização da história do Brasil a partir dos estudos de Décio Saes (1985) que na obra A formação do estado Burguês no Brasil (1888-1891), referenciado no Materialismo 
Histórico, considera o modo de produção dominante como o fundamento de toda a história superestrutural, e considerando que o Escravismo Moderno, que Gorender (1985) chama de "Escravismo Colonial", dominou a infraestrutura brasileira de 1532 até o final do século XIX, propõe uma cronologia política fundamentada nas fases desse escravismo, a saber: Estado Escravocrata Moderno Colonial (1549-1808); Estado Escravocrata Moderno Semicolonial (1808-1831); Estado Burguês (1888-atual).

Apesar do presente estudo ter como objeto a História do Brasil e não a História Geral, devido à periodização do material avaliado ser eurocêntrica julgou-se necessário analisar, além da História do Brasil, conceitos do que é História e da própria periodização da História.

O estudo do material está subdividido em sete unidades de análises que correspondem a perspectiva da periodização da História do Brasil adotada pela autora da presente pesquisa.

\section{Unidade de Análise: Refletindo sobre História}

O que é história? Quando esta ciência surgiu? Quais são os povos que têm história? Como a história está dividida? Quem realizou essa periodização?

Estas e outras questões devem ser tratadas com os estudantes principiantes. No entanto, no ensino médio, imagina-se que os discentes já tiveram tempo para refletir sobre estes temas e, nesse momento da vida escolar, terão a oportunidade de abordar com mais experiência e, portanto, com maior criticidade, diferentes períodos da história. E o material didático será mais um recurso para guiá-los, proporcionando-lhes ampliar conhecimentos sobre a diversidade étnica, de gênero, religiosa, política etc.

Contudo algumas questões perduram: Será essa a realidade? Qual a visão de mundo presente no material disponibilizado a estes estudantes? A população negra e ameríndia estará contemplada nestes manuais? 
Para tentar responder a tantos questionamentos, buscou-se primeiramente o caderno do aluno e do professor destinados ao ensino médio. A resposta foi o silêncio, uma vez que não há nenhuma situação de aprendizagem que discuta o conceito de história e a sua periodização atual.

No livro didático adotado por algumas escolas públicas estaduais, Cotrim (2013a) aborda os temas históricos com uma visão eurocêntrica e colonizada, reproduzindo a obra Três idades, de Jules Scalbert, com três gerações de mulheres brancas, propondo uma reflexão sobre o passado, presente e futuro. Na página seguinte do livro, tem-se a pintura intitulada Tempo, de Pieter Cornelis Wonder, retratando um homem branco idoso e alado, com a proposta de pensar sobre as mudanças e as permanências históricas.

Figura 1: As três idades, de Jules Scalbert

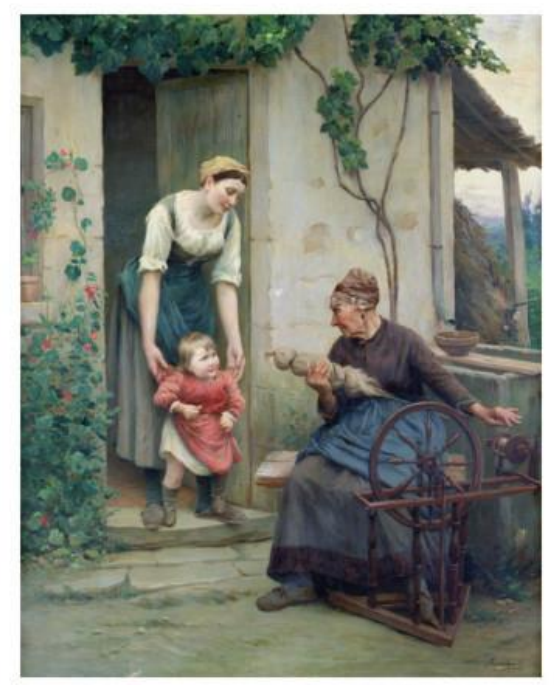

Disponível em: http://www.allposters.com.br/-sp/The-Three-Ages-posters i4044753 .htm

Após a exibição das duas figuras, o autor propõe a exploração dos sentidos da palavra história, que, por ser polissêmica, "[...] possui diversos significados como ficção, vivência e memória e área de conhecimento" (COTRIM, 2013a, p. 11). 
As primeiras menções à população negra referem-se às fontes escritas e não escritas. Como exemplo da primeira, tem-se um recibo de compra e venda de um escravizado, datado de 1858. Para exemplificar uma fonte não escrita, o autor apresenta a obra Uma senhora de algumas posses em sua casa, de Debret, de 1823.

Figura 2: Uma senhora de algumas posses. Debret 1823.

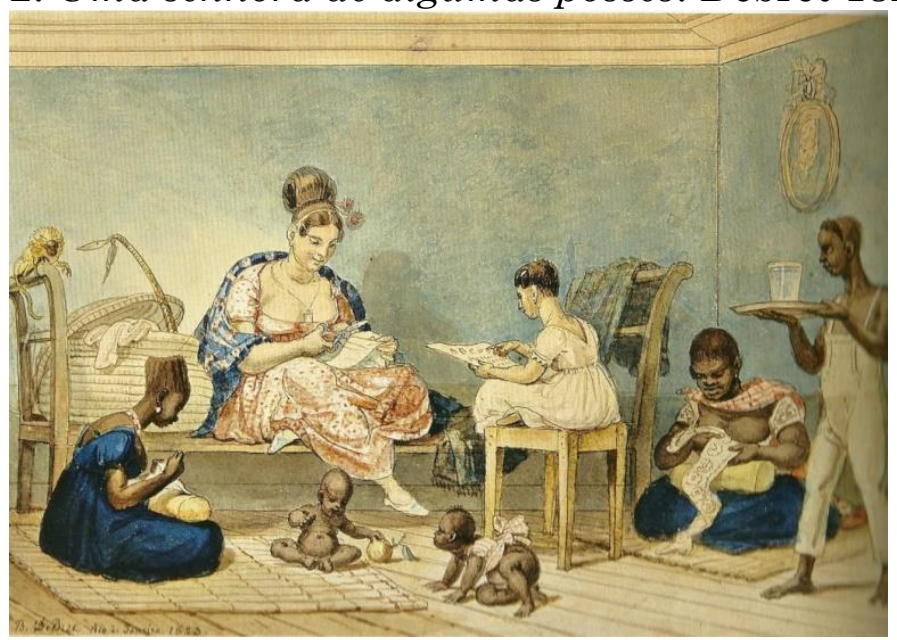

Disponível em: http://www.ensinarhistoriajoelza.com.br/contrastes-sociais-brasil-coloniadebret/

Com relação à medição do tempo, tem-se apenas o calendário cristão, a representação de um relógio mecânico da Europa ocidental e a reprodução de um manuscrito francês extraído do Manual agrícola, de Pietro de Crescenzi, representando diversas atividades agrícolas, de acordo com os meses do ano.

No item seguinte, periodizações históricas, o autor explica que é possível realizar distintas periodizações da história, com enfoque econômico, político, tecnológico, ideológico, cultural etc. Prossegue apresentando a periodização tradicional, explicitando que esta foi elaborada por historiadores europeus, que estabeleceram como marco divisório das "idades" acontecimentos ocorridos na Europa, desconsiderando a história das outras sociedades. Apesar do autor citar a possibilidade de outras periodizações da história, a única explicitada é a tradicional: i) Pré-história (até 4000 a.C.); ii) Idade antiga (4000 a 476 d.C.); iii)Idade média (476 d.C - 1453 d.C.); iv) Idade 
moderna: da tomada de Constantinopla até a Revolução Francesa (1789); v) Idade contemporânea até os dias atuais.

Com a descrição da primeira unidade de análise, é possível observar a opção do autor por representar o tempo e a história com um enfoque eurocêntrico, em que o homem branco é tido como representante da espécie humana. Das onze figuras reproduzidas na unidade, sete são pessoas brancas, duas aludem ao negro (como escravizado) e duas a povos ameríndios sem distinções étnicas.

Nesta primeira etapa da análise do material didático de história, têm-se dois temas que merecem maior atenção: primeiro, o material didático faz referência à periodização eurocêntrica da história, dando a entender que irá problematizar a questão, apresentando outras perspectivas; contudo, essa problematização não ocorre e repete-se a periodicidade tradicional, reforçando a colonialidade do poder e do saber, tanto nos textos como nas imagens. Deste modo, não existe uma revelação dos motivos sombrios dessa organização da história. O tempo continua sendo apresentado de maneira linear e abstrata e a Europa é o "centro", com uma história oficial organizada a partir da memória e feitos dos opressores coloniais, com a hegemonia do eurocentrismo como perspectiva de conhecimento (TAVARES, 2014).

O segundo tema é a sub-representação da população negra; as duas menções ao negro são como escravizados. O negro é representado como empregado doméstico e animal de estimação, servil, dócil e conformado.

\section{Unidade de Análise: Primeiros Povos da América}

A unidade tem início explicitando as duas hipóteses sobre a chegada dos primeiros seres humanos à América: o estreito de Bering e o Oceano Pacífico. Em seguida, a exposição aborda que os fósseis mais antigos da América foram encontrados no Brasil, sendo a Luzia, com aproximadamente 11,5 mil anos, "a mulher mais velha do continente". O texto também cita as pesquisas 
arqueológicas em São Raimundo Nonato (PI), que indicam que homens e mulheres habitaram a região há aproximadamente 50 mil anos.

Este seria um momento oportuno para a unidade de leitura apresentar uma imagem da Luzia e problematizar a hipótese dos nossos antepassados serem africanos; ou seja, o negro não chegou ao Brasil apenas a partir do processo de escravização, mas muito antes dos europeus migrarem para o continente, contribuindo para a formação do povo brasileiro. No entanto, não há nenhuma imagem de Luzia e a problematização não ocorre.

\section{Unidade de Análise: Invasão Europeia}

Nessa unidade, Cotrim (2013a) discute se o continente americano foi "conquistado" ou "descoberto". Explica que o uso das palavras "conquista" e "conquistadores" foi proibido pelos espanhóis, sendo substituídas pelas palavras "descobrimento" e "colonos". O autor procura demonstrar que existia e existe no Brasil uma diversidade de povos nativos que foram classificados pelos europeus como "índios", sem respeito às suas particularidades culturais e biológicas.

O caderno do aluno, na situação de aprendizagem VIII "A vida na América antes da conquista europeia: as sociedades maias, inca e asteca", como o título sugere, não trata da vida no Brasil antes da primeira invasão portuguesa, ficando circunscrito ao território vitimado pelos espanhóis.

Desse modo, ao tratar a invasão europeia, o livro analisado é mais progressista que o caderno do aluno, porque o primeiro problematiza o uso da linguagem pelos colonizadores, que proibiam o uso das palavras "conquista" e "conquistadores"; o caderno do aluno, mais uma vez se silencia sobre a discussão e aborda somente a vida na que foi posteriormente denominada "América espanhola", deixando uma lacuna a respeito do território brasileiro antes da chegada dos invasores europeus. Novamente será necessário refletir sobre o silêncio, o não dito, que pode ser traduzido como a manutenção do mito de que antes da chegada dos europeus, o Brasil era uma terra de selvagens, 
de grupos que não produziam qualquer cultura, de um bando de canibais sem religião ou temor a Deus e, que, portanto, a colonização trouxe o progresso a esta terra de ninguém.

O não dito do caderno do aluno e do professor, acrescido à discussão superficial a respeito da situação objetiva de opressão imposta aos povos nativos é simbólico da conquista, que rouba as palavras dos oprimidos.

E por estar a serviço do sistema opressor, a escola é grande aliada, mantendo vivo o mito da inferioridade ontológica dos oprimidos e o da superioridade dos opressores. A superação da manutenção da situação de opressão a partir dos mitos exige sua problematização com os oprimidos.

Essa problematização poderia ser realizada no ambiente escolar, tendo o material didático como aliado. Entretanto, se se considerar que a cultura escolar propicia aos indivíduos um corpo comum de categorias de pensamento (BORDIEU, 1999), a escola continua transmitindo o consenso cultural de lugares-comuns e o currículo de História permanece com uma abordagem linear e superficial, no caso em tela, da história da América antes da invasão europeia.

\section{Unidade de Análise: Estado Escravocrata Moderno Colonial (1549-} 1808)

A fase colonial do escravismo brasileiro é apresentada no segundo volume do livro da coleção analisada. Este período é exposto de forma linear. Seguem os principais pontos abordados: i) Primeiro Governo-Geral; ii) Segundo Governo-Geral; iii) Terceiro Governo-Geral.

Os dois capítulos subsequentes são particularmente interessantes para a presente pesquisa pois têm como temas: a economia colonial, escravização e resistência. Primeiramente, o autor explica porque a cana-de-açúcar era um negócio lucrativo e que a sociedade açucareira era composta por “[...] senhores, escravos e pessoas de diversas ocupações: feitores, mestres de açúcar, purgadores, agregados, padres e alguns funcionários do rei e profissionais 
liberais" (COTRIM, 2013b, p. 32). Em seguida, há uma referência ao livro Casa-grande e senzala, de Gilberto Freyre, acompanhado da explicação que:

A casa-grande era o casarão onde moravam o senhor de engenho [...], a senzala era a construção onde viviam os escravos africanos e seus descendentes [...]. As senzalas consistiam geralmente de cabanas separadas, de paredes de barro e telhado de sapé, ou, mais caracteristicamente, de construções enfileiradas divididas em compartimentos, cada um ocupado por uma família ou unidade residencial (id., ib., p. 33).

Logo depois, têm-se as explicações dos motivos que levaram à adoção da mão de obra escravizada dos africanos. Encerrando o capítulo "Economia colonial: o açúcar", consta um texto de Schwartz, intitulado "Cotidiano dos escravos nos engenhos", que se refere aos castigos, vestuário, alimentação e à teoria dos três $\mathrm{P}$ (na qual o escravizado precisava de pão, pano e pau) de Antonil. Citando Stuart Schwartz, o texto informa que os africanos não eram mais predispostos ao cativeiro do que os índios ou outros povos, mas as "[...] semelhanças de sua herança cultural com as tradições europeias valorizavamnos aos olhos europeus"(COTRIM, 2013b apud SCHWARTZ, 1988, p.36).

A leitura do capítulo "Economia colonial: o açúcar" possibilita a reflexão sobre importantes temas. Primeiramente, considerando que várias fontes, incluindo relato de viajantes, descrevem as senzalas como: "[...] alojamento dos escravos, que ficava numa comprida e suja construção de um só piso que exteriormente tinha uma grande semelhança com uma cavalariça [...]. Nos quartos dormem seis até oito juntos" (ADALBERTO, 2002, p. 130); “as senzalas - habitações coletivas dos negros escravos - eram construções bastante longas, sem janelas, dotadas de orifícios junto ao teto para efeito de ventilação e iluminação" (PINSKY, 1998, p. 38); por que o material didático apresenta as senzalas como constituídas “[...] geralmente de cabanas separadas [...] cada uma ocupada por uma família” (COTRIM, 2013b, p. 33)? 
Qual a intencionalidade em reproduzir essa versão pouco recorrente das senzalas?

Em segundo lugar, ao tratar os motivos que contribuíram para adoção do trabalhador escravizado africano em detrimento do nativo, tem-se a explicação de que o "[...] indígena masculino não se acostumou ao trabalho na lavoura, que era incumbência das mulheres" (id., ib., p.35). Seria o africano mais adaptado ao trabalho (escravizado) na lavoura que o nativo? Se o trabalho nas lavouras era incumbência das mulheres, teria o escravizador se compadecido das mulheres nativas, não as submetendo ao trabalho escravizado?

Em contrapartida, o texto também informa que o tráfico de africanos escravizados era muito lucrativo e que os africanos detinham conhecimentos que interessavam ao processo de produção do colonizador.

A unidade analisada, por um lado, mais progressista, traz informações pouco discutidas anteriormente à Lei n. ${ }^{\circ}$ 10.639/03, como a lucratividade do tráfico de africanos e os conhecimentos prévios desses como uma vantagem comparativa à mão-de-obra indígena; mas, por outro, continua apoiando o mito da passividade do escravizado africano e utiliza-se do discurso que deveria ser positivo (os africanos terem conhecimentos valorizados pelos europeus) para justificar a substituição da escravização dos nativos por africanos. Além disso, prossegue com uma visão mais humanizadora da escravização, com famílias de escravizados que têm sua privacidade preservada, vivendo em cômodos separados. Este tipo de afirmação é tendenciosa e, possivelmente, refere-se a alguns casos isolados e não à realidade generalizada no Brasil escravocrata, em que as famílias eram separadas no momento da venda, os filhos e filhas eram arrancados dos braços das mães, que deveriam servir de ama-de-leite para os ioiôs e iaiás, as meninas eram estupradas pelos escravizadores e agregados etc. Considerando essa realidade, é risível se afirmar, no livro didático, que as "[...] senzalas eram cômodos separados em que viviam as famílias"! 
Mais uma vez, o material didático mostra-se favorável a uma História Oficial do Brasil que repete estereótipos, que não problematiza os processos de opressão, não alude à dicotomia da escravização, em que os escravizados (negro e autóctone) são responsáveis pela produção de riqueza que, além de manter a economia colonial, financiou o desenvolvimento do capitalismo europeu; mas, na condição de escravizados, foram totalmente excluídos dos direitos de usufruírem do fruto do seu trabalho.

O capítulo subsequente, intitulado "Escravidão e resistência", principia com uma reprodução da obra Mercado da Rua do Valongo, de Debret (fig. 3).

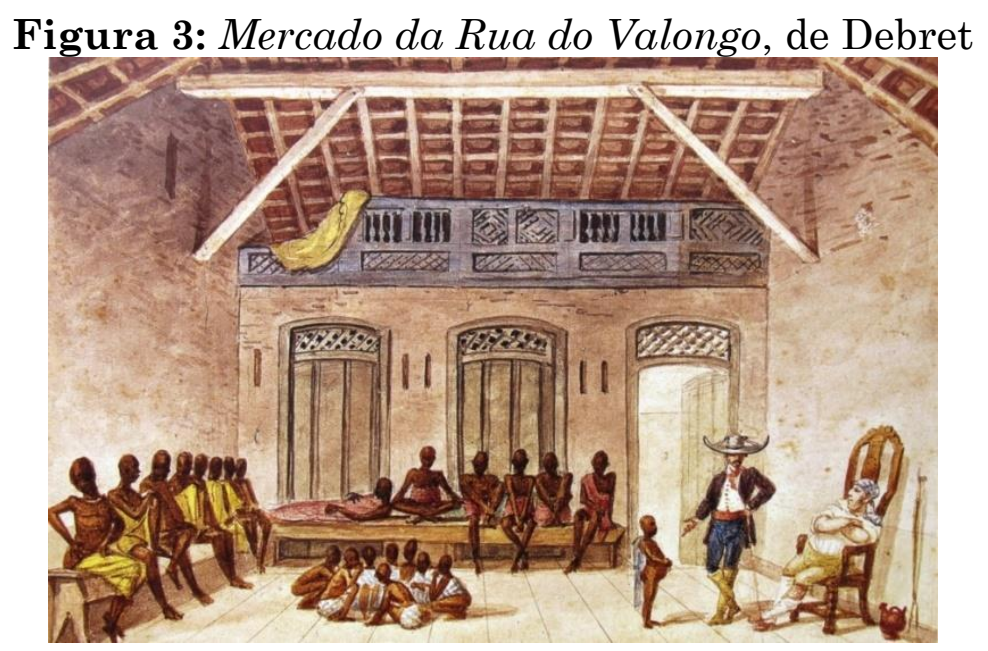

Fonte: https://outrora.info/index.php?title=Mercado_da_Rua_do_Valongo/Debret

A cena captada pelo pincel retratista do pintor francês é de uma sala ampla com africanos sem correntes, adultos sentados ou deitados em bancos, de pernas cruzadas, alguns em posição de descontração. Quase no centro da cena, crianças agachadas em roda, como se realizassem algum jogo; no canto direito, dois brancos, supostamente o mercador de seres humanos escravizados e um possível comprador analisando uma criança. Apesar de se tratar de uma cena que retrata o comércio de seres humanos, o mercado é de cor clara, de certa forma, acolhedor; os africanos estão em posições que os retratam tranquilos; não há instrumentos de tortura ou humilhações e as crianças até parecem brincar. Ora, o estudante que observe esta cena não achará que o comércio de seres humanos era algo tão terrível. Afinal a cena é 
até harmônica. Mais uma vez, Debret realiza um "registro" atenuante da escravização no Brasil e os livros didáticos continuam copiando suas obras sem nenhum questionamento dessas reproduções.

No mesmo capítulo ("Escravidão e resistência"), pode-se encontrar: a) texto sobre o "tráfico negreiro", explicando que, muito antes dos europeus, os árabes já realizavam o comércio escravista de africanos; b) texto "Número do comércio de escravos", informando que se estima que quatro milhões de africanos foram traficados para o Brasil; c) texto "A diversidade étnica", em que os africanos sequestrados e traficados para o Brasil, eram em sua maioria bantus e sudaneses; d) texto "Distinções entre africanos escravizados", que alude às atividades laborais dos trabalhadores escravizados - "escravo" de ganho, negro do eito, "escravos" domésticos.

Encerrando o capítulo, há três laudas dedicadas às diversas formas de resistência à escravidão, com ênfase à prática da capoeira e ao Quilombo dos Palmares; há ainda um parágrafo sobre Ganga Zumba, um a respeito de Zumbi e dois destinados à destruição de Palmares.

Deste modo, as dez laudas destinadas à escravização e à resistência negra pouco contribuem para a valorização da ancestralidade do descendente africano, além de ser tendenciosa, ao informar que "[...] a escravidão foi uma prática tão antiga quanto perversa e [...] no caso do comércio escravista de africanos, sabe-se que os árabes, muito antes dos europeus, já adquiriam africanos no centro-sul da África” (COTRIM, 2013b, p. 39).

Essas afirmações sugerem que a escravização dos africanos pelos portugueses foi apenas continuidade da uma atividade "comercial" que já era frequente; os portugueses apenas implementaram o sistema, com o tráfico Atlântico.

No que diz respeito à diversidade étnica dos cativos, o autor ainda segue as teorias ultrapassadas de Sílvio Romero (século XIX) e Nina Rodrigues (década 1930), que apontavam para um exclusivismo bantu, no caso do primeiro, e sudanês, no do segundo, desconsiderando estudos como de Artur Ramos (1979, p. 49), da década de 1930, que informa que os negros 
escravizados provinham de todas as partes da África, uma vez "[...] que eram capturados em qualquer região, sem discriminação de procedência e embarcados em portos da costa”.

O livro didático analisado não se aprofunda na discussão sobre a diversidade étnica e cultural dos africanos escravizados e reduz as atividades laborais a três, ignorando estudos como de Gorender (1985) que demonstrou a presença do(a) negro(a) escravizado(a) em todos os setores de atividades, sendo que o escravismo constituiu o modo de produção dominante durante grande parte dos séculos XVIII e XIX.

A respeito da resistência à escravidão, o material didático reproduz a foto de dois capoeiristas, acompanhada de texto sobre a resistência dos africanos e descendentes, que explica que os negros não ficaram passivos à condição de escravizados(as), exercendo várias formas de resistência, como violência contra si mesmos, fugas individuais e coletivas, confrontação, boicote, sabotagem e negociações. Esta parte do texto é um avanço, por, finalmente, abordar a escravização como condição histórica e por ressaltar que os(as) escravizados(as) exerceram várias formas de resistência.

Contudo, ao apresentar a resistência quilombola, o texto é superficial, se atém apenas ao Quilombo dos Palmares e subestima o fato de que houve cerca 20 mil habitantes: "[...] o número provavelmente era menor; acredita-se que tenha sido aumentado pelo governador para justificar o fracasso das primeiras expedições militares" (COTRIM, 2013b, p. 46). Afora isso, a atuação de Ganga Zumba e Zumbi são minimizadas e, no único parágrafo dedicado a Ganga Zumba, dois terços é para descrever o acordo que Zumba firmou com o governador, que não beneficiava os negros recém-chegados ao quilombo. $\mathrm{O}$ capítulo encerra-se com um box sobre o dia da Consciência Negra.

Evidencia-se que o livro didático, além de subestimar o número de quilombolas (afirmando que a informação de 20 mil habitantes é um exagero do governador da época), reduz o tempo de luta e resistência de Palmares, informando que "[...] o quilombo resistiu por 65 anos" (COTRIM, 2013b, p. 46) e se cala frente às centenas de outros quilombos que existiram em todo o país, 
como Kalunga (GO), Ambrósio (MG), Campo Grande (SP), Urubu (BA), Preto Cosme (MA) e tantos outros que ainda hoje têm remanescentes quilombolas e que continuam lutando para ter o direito à terra e a manter suas tradições.

O que se pode perceber é que se, por um lado, o material didático procura atender aos dispositivos da Lei n. ${ }^{\circ}$ 10.639/03, resgatando a contribuição do povo negro, assim como sua história de resistência, por outro, a abordagem é, em geral, insuficiente pois diminui a importância dos quilombos e não propõe uma discussão sobre as comunidades quilombolas e, por consequência, desconhece olimpicamente a situação dos negros no Brasil contemporâneo. Trata-se de um conteúdo progressista, mas, ainda com um viés racista.

No capítulo "Economia colonial: mineração", a exemplo do capítulo anterior ("Escravidão e resistência") o protagonismo negro não é evidenciado. Não há destaque ao papel exercido pelos negros escravizados, livres e libertos no desenvolvimento da economia e da cultura mineira no século XVIII e, apesar de citar Antônio Francisco Lisboa, o Aleijadinho, e Manuel Costa Ataíde, o mestre Ataíde (artista plástico), assim como os compositores Américo Lobo Mesquita e Francisco Gomes da Rocha, em nenhum momento, o texto informa que esses artistas eram negros. Igualmente, não faz referência ao tipo de escravização perversa realizada nas minas, nem sobre a luta antirracista protagonizada pelos negros escravizados e libertos, que negavam a ordem escravocrata com organização de quilombos, buscando a dignidade e a compra de alforrias, a partir das ordens religiosas como da Irmandade da Senhora do Rosário dos homens pretos.

Observa-se que o capítulo destinado à mineração, não destaca que o desenvolvimento desta atividade econômica financiou o desenvolvimento do Estado de Minas Gerais, a riqueza de Portugal e, por conseguinte, da Inglaterra; que teve o trabalho escravizado como propulsor e o trabalhador negro escravizado é representado como coadjuvante, enquanto deveria ser apontado como categoria social formadora da sociedade mineradora. 


\section{Unidade de Análise: Estado Escravocrata Moderno Semicolonial (1808-1831)}

Neste período da história do Brasil em que o país foi invadido novamente pelos portugueses, os destaques do livro didático são: i) Chegada da corte portuguesa ao Brasil; ii) Governo de Dom João; iii) Elevação do Brasil a Reino Unido, iv) Revolução Pernambucana; v) Retorno da corte a Portugal; vi) Independência do Brasil; vii) Primeiro Reinado; viii) Primeira Constituição; ix) Confederação do Equador; x) Guerra da Cisplatina e xi) Abdicação do trono.

Em todos esses episódios, a participação dos negros é explicitada apenas no processo de independência:

[...] os escravos foram recrutados para lutar a favor da Independência [...]. A voz dos escravos quase não aparece na vasta documentação sobre o recrutamento e a libertação pós-guerra. Mas eles viam a Independência e as lutas como meios de conquistar a liberdade (KRAAY, 2009 apud COTRIM, 2013b, p. 227).

$\mathrm{Na}$ Revolução Pernambucana não há menção à luta dos negros, que compunham a parcela empobrecida da população e que apoiaram a revolução. Portanto, nesta fase da história, o livro didático invisibiliza a população negra e não propõe a discussão do porquê essa população não ser contemplada com liberdade e igualdade aludida na primeira Constituição do país, resultado da pessoa negra ser tida, pela lei, como bem semovente, na mesma categoria de um animal de carga.

Perde-se, aí uma oportunidade de discutir o racismo e os motivos que o justificaram ao longo dos séculos, como reduzir os negros a coisas, desumanizando-os.

No momento histórico em que a corte portuguesa se refugia no Brasil, aumentando impostos e ampliando ainda mais a exploração do povo, o aparato 
burocrático e jurídico serve ao Estado e mantém a escravização e a redução da população negra à condição de escravizado e, o que é pior, à condição de "não-humano".

\section{Unidade de Análise: Estado Escravocrata Moderno Nacional (1831-1888)}

A fase histórica que compreende o período nacional é marcada pela insatisfação de diferentes camadas da população, o que resultou em revoltas e movimentos de e por reformas. Os primeiros envolviam diferentes setores da população e reivindicavam mudanças sociais, como o fim da escravização dos africanos e afro-brasileiros; os segundos buscavam satisfazer demandas de determinados grupos sem modificar a estrutura social do país.

O livro didático em análise discorre sobre os seguintes movimentos: Cabanagem, Farroupilha, Balaiada, Praieira e por fim, a Revolta dos Malês, que ocorreu em Salvador, em 1835.

De acordo com Gomes e Munanga (2016) várias revoltas populares tiveram a presença negra como protagonista central, dentre as quais podem ser destacadas: a revolta dos Alfaiates (Bahia, 1798), a Cabanagem (Pará, 1835-1840), a Sabinada (Bahia, 1837-1838), a Balaiada (Maranhão, 18381841), a dos Malês (Bahia, 1835). Nessas revoltas, os escravizados realizaram formas superiores de luta a favor da liberdade e da destruição do modo de produção escravista moderno.

No livro didático, apenas na Revolta dos Malês, o componente negro tem destaque, ainda assim de forma equivocada. $\mathrm{O}$ autor simplifica a abordagem, informando que se tratava de uma "[...] revolta de escravos africanos conhecidos como malês [...], o nome malê era a designação dada na Bahia aos africanos de origem ou formação muçulmana" (COTRIM, 2013b, p. 247). Apesar de o material didático ser da década de 2010, o autor ignora estudos realizados anteriormente, como o de Freitas, que contesta essa teoria e informa que, ao contrário do que o nome da revolução sugere (malês), ela tinha 
como maioria os insurgentes nagôs, que contaram com elementos de muitas outras nações. Houve uma aliança entre muçulmanos e animistas e "[...] a arregimentação dos insurretos se fez a (sic) nível político e não religioso" (FREITAS, 1976, p. 73).

Como se pode observar, o negro escravizado não é apresentado no material didático como agente coletivo, como contestador do sistema de construção da riqueza; ao contrário, os textos sobre os movimentos de revoltas na fase nacional repetem estereótipos e não problematizam a contradição entre escravizados e escravizadores, que resultaram em movimentos contínuos de contestação.

\section{Unidade de Análise: Estado Burguês (1888-atual)}

A última etapa da história do Brasil compreende a fase do Estado Burguês e é apresentada na $3 .^{a}$ série do ensino médio. O volume III do livro de Cotrim (2013c) trata o período a partir da instituição da República.

Iniciando a unidade dois, denominada Da República à era Vargas, há uma reprodução do óleo sobre tela, Alegoria à proclamação da República e à partida da família imperial, de autor desconhecido.

Nessa obra, Deodoro da Fonseca e líderes republicanos são representados entregando a bandeira da República a uma figura feminina. A República é representada por uma mulher branca, com vestimenta grecoromana. Os republicanos são todos homens brancos com feições de portugueses. No lado esquerdo da imagem, há duas mulheres negras com vestimentas simples, que se mostram alheias ao acontecimento.

De acordo com Cotrim (2013c, p. 73), “[...] a queda do regime monárquico e a proclamação da República ocorreram num clima de ordem e concordância entre as elites". Prossegue com o relato de Aristides da Silva Lobo, que teria dito: "[...] o povo assistiu a tudo bestializado". A forma como a mudança do regime monárquico para a República é exposta, além de tratar da mudança, 
e, não da natureza do Estado, corrobora o mito da passividade do povo brasileiro.

O tema subsequente da segunda unidade de ensino é a primeira Constituição da República. O texto explica que, no Brasil, adotou-se a forma de governo republicana, com sistema presidencialista, divisão de poderes e direito ao voto garantido aos brasileiros maiores de 21 anos, excetuando-se "[...] analfabetos, mendigos, soldados e religiosos sujeitos à obediência eclesiástica. As mulheres também não podiam votar" (COTRIM, 2013c, p. 75). Ou seja, mantinha-se o mecanismo de exclusão, no qual os negros, de forma indireta, eram também excluídos, uma vez que a maioria era analfabeta, sem emprego e sujeita à mendicância.

Prosseguindo, tem-se, cronologicamente: o governo de Deodoro da Fonseca e o governo de Floriano Peixoto, classificados como "República da Espada". Vem, em seguida, o governo de Prudente de Morais, dando início à "República Oligárquica", com influência dos grandes coronéis no processo político e eleitoral. Finalmente, emerge a "República café-com-leite".

O negro é representado nesse período por duas ilustrações: a primeira, uma fotografia de Marc Ferrez, que registrou o trabalho de escravizados em 1882 e a segunda é uma ilustração do movimento no porto de Santos, com três negros estivadores, carregando pesados sacos de café nas costas.

Ao tratar da sociedade brasileira, Cotrim (2013c, p. 90) destaca que "[...] o período da primeira República também foi marcado pela grande imigração, principalmente europeia e pelo avanço industrial no país". Sobre o movimento operário, a única alusão aos trabalhadores negros refere-se ao fato de que 31\% das indústrias brasileiras concentravam-se em São Paulo, local onde "[...] havia um grande número de ex-escravos e seus descendentes" (id., ib., p. 92).

O capítulo intitulado As revoltas na primeira república traz: a) Guerra dos Canudos; b) Guerra do Contestado; c) Cangaço; d) Revolta da Vacina; e) Revolta da Chibata; f) Tenentismo. Seguindo a tendência do silenciamento da participação da população negra na história do Brasil, o referido capítulo não menciona a participação de Manuel Ciríaco e Antônio Pajeú, dois negros 
estrategistas que, junto a outros, defenderam Canudos das tropas militares da República (KORNIJESUK, 2012). Tão pouco aponta a participação de negros nas duas partes do conflito do Contestado, revolta que explodiu na região sul do país (RAMOS, 2016). Igualmente, não faz referência à população negra no Cangaço, nem na Revolta da Vacina. O texto prossegue tratando da Revolta da Chibata, com uma única menção aos negros. Ao fím de duas páginas, o autor diz que João Cândido "[...] passou para a história como o Almirante Negro".

Os períodos seguintes discutidos no livro História Global são intitulados: "Era Vargas e o Brasil nos dias atuais". Os textos descrevem o processo que levou Getúlio ao poder em 1930; o movimento constitucionalista de 1932; a Constituição de 1934; o governo ditatorial e a instituição do Estado Novo; a supressão de partidos políticos com a clandestinidade do Partido Comunista, avançando até leis trabalhistas e o Populismo.

Finalizando o livro didático, os textos versam sobre a Constituição de 1946, o governo de Eurico Gaspar Dutra (1950-1954) e a política anticomunista e autoritarismo; o retorno de Vargas ao poder; a morte de Vargas; o desenvolvimentismo da era Juscelino Kubitschek; a governo Jânio Quadros; o governo João Goulart e reformas de base; o golpe militar de 1964 e atos institucionais, com os movimentos de protesto, a luta armada, a transição do regime militar para a democracia; a redemocratização, com a Constituição Federal de 1988, governo Fernando Collor de Mello, a presença indígena, o governo Itamar Franco, o governo Fernando Henrique Cardoso; lutas dos povos indígenas no século XXI e, finalmente os governos Luís Inácio Lula e o governo Dilma Roussef.

$\mathrm{O}$ caderno do aluno e o do professor não fazem nenhuma referência à luta negra em todo esse período. Mais uma vez, o silêncio, o não dito no currículo de história demonstra o caráter racista do material didático, que sequer cita as revoltas populares do início do século $\mathrm{XX}$, não discute a resistência negra durante a ditadura de Vargas e ditadura militar de 1964- 
1985, não se refere aos artistas negros que também se opuseram às torturas e sistemas ditatoriais etc.

E considerando que o período estudado é posterior ao Estado Escravocrata Moderno, o que justifica a foto de negros escravizados em 1882, se o autor está tratando da produção de café no século XX? Por qual razão o(a) negro(a) só foi representado como escravizado(a) e seminu(a) com sacas de café às costas? Por que, quando o objeto de estudos são os operários, a população negra é denominada de “ex-escrava e seus descendentes”? E qual a intenção do autor ao associar a imigração europeia ao desenvolvimento industrial do país?

As respostas a estes questionamentos explicita o racismo oculto, implícito em todo material didático, que coisifica a população negra, trata-a como ex-escrava e não como trabalhadora; associa essa população ao trabalho braçal e continua a representá-la como escravizada, mesmo após a abolição desse perverso modo de produção. Em contrapartida, existe um enaltecimento do imigrante europeu, que substituiu a mão de obra negra e colaborou para o desenvolvimento econômico do país, reforçando as ideias de que o negro é que atrasava o País. Apesar de subentendido, existe um viés racista que reforça a ideologia do branqueamento.

É impressionante como os textos do material didático analisado incorporam essa ideologia e são negligentes ao não relatarem os exemplos de resistência negra após abolição, reforçando a ideia de que, após a assinatura da Lei Áurea, a situação do negro no Brasil ficou harmoniosa, sem demonstrar que a população negra continuou a viver em situação de desigualdade no Estado Burguês.

No que diz respeito ao período de 1930 a 2012, não há nenhuma referência às reivindicações da população negra; ao desenvolvimento da imprensa negra na década de 1930; à transformação da Frente Negra em partido político; ao teatro experimental do negro (TEN) na década de 1940; à participação de Marighela em oposição à ditadura do Estado Novo de Getúlio. Aliás há uma única referência a Marighela no item "Luta armada", na 
ditatura da década de 1960, mas sem citar que era um líder negro e sem versar sobre a resistência negra na ditadura militar.

Silêncio completo sobre a luta dos negros para se inserirem na indústria que se estabelecia na região sudeste do país; nenhuma frase a respeito da manifestação de vários grupos negros, em 1978, em frente ao teatro municipal de São Paulo que resultou na criação do Movimento Negro Unificado. Igualmente, o material analisado não aludiu à Marcha para Zumbi, em 1995, nem às reivindicações do movimento negro, não atendidas durante o governo de Fernando Henrique Cardoso. Em alguns momentos, o texto menciona a luta dos indígenas, suas conquistas etc., mas não há referência ao movimento quilombola, à violência urbana e à miséria a que a população negra é submetida.

Deste modo, a análise da presença/ausência da população negra no material didático no Estado Burguês revelou que não há nenhuma citação relativa à luta desta população por melhores condições de vida. Os autores praticamente não discutem a resistência dos negros no período entre $1889 \mathrm{e}$ 2012 e, quando se referem à população negra, ela é denominada de "exescravos e seus descendentes" (COTRIM, 2013c, p. 92).

As ilustrações do capítulo que alude ao período de 1889 a 1930 continuam retratando os negros escravizados, apesar de versar sobre a economia no período pós-abolição.

\section{Considerações Finais}

A análise do material didático de história revelou uma posição retrógrada de autores considerados "progressistas". Ao observar o silenciamento com relação à resistência negra desde o início da escravização até os dias atuais; o tratamento superficial ao abordar as revoltas populares que ocorreram e tiveram a presença do povo negro como protagonistas e as alusões ao progresso associado ao imigrante branco europeu, é possível entender porque um material didático desenvolvido à luz da Lei n. ${ }^{\circ}$ 10.639/03, 
apresentando tópicos que teoricamente atendem às determinações da norma, mostrou-se progressista na forma, mas mantendo-se racista em seu conteúdo ocultado pelo silêncio ou pelo não-dito.

Deste modo, ao término da análise do material didático do ensino médio do Estado de São Paulo, pode-se entender que a questão negra é apresentada como periférica. Contudo, considerando a questão econômica como última instância, tem-se o negro, no período do Escravismo Moderno (1532-1888) e no Capitalismo (1888-atual), como elemento central e, portanto, faz-se necessário a elaboração e discussão de uma teoria dialógica e revolucionária, que se contraponha à teoria antidialógica e opressora, que continua em vigor na sociedade brasileira, tendo as instituições escolares como aliados no processo de alienação e opressão da população negra e periférica, proibindo os seres humanos de serem mais e de realizarem a síntese cultural que supere a cultura alienada e alienante que é imposta.

\section{Referências}

ADALBERTO, Príncipe da Prússia. Brasil: Amazonas-Xingu. Tradução de Eduardo de Lima e Castro. Brasília, DF: Conselho Editoria, 2002. (O Brasil visto por estrangeiros).

BRASIL. Lei n. $^{\circ} 10.639$ de 09 de janeiro de 2003: altera a Lei ${ }^{\circ} 9.394$, de 20 de dezembro de 1996, que estabelece as diretrizes e bases da educação nacional, para incluir no currículo oficial da rede de ensino a obrigatoriedade da temática História e Cultura Afro-Brasileira, e dá outras providências. Brasília, DF, 2003. Disponível em: <http://www.planalto.gov.br/ccivil_03/leis/2003/l10.639.htm>. Acesso em: 24 jun. 2014.

BOURDIEU, P. A economia das trocas simbólicas. 5. ed. São Paulo: Perspectiva, 1999.

COTRIM, G. História Global: Brasil e geral. 2. ed. Saraiva: São Paulo: 2013a. v. 1.

História Global: Brasil e geral. 2. ed. Saraiva: São Paulo: 2013b. v. 2.

. História Global: Brasil e geral. 2. ed. Saraiva: São Paulo: 2013c. v. 3.

DEBRET, J.-B. Mercado da Rua do Valongo. In:__. Viagem pitoresca e histórica ao Brasil. 3. ed. São Paulo: Livraria Martins Editora, 1954. (Biblioteca Histórica Brasileira, v. IV). p. 188-190. Disponível em: 
$<$ https://outrora.info/index.php?title=Mercado_da_Rua_do_Valongo/Debret $>$. Acesso em: 15 dez. 2016.

. Uma senhora de algumas posses. Aquarela sobre papel, 16,2 x $26 \mathrm{~cm}$. Rio de Janeiro, 1823. Disponível em: <http://www.ensinarhistoriajoelza.com.br/contrastessociais-brasil-colonia-debret/>. Acesso em: $15 \mathrm{dez} .2016$.

FREIRE, Paulo. Pedagogia do Oprimido. São Paulo: Paz e Terra, 2005.

FREITAS, D. Palmares: a guerra dos escravos. 5. ed. Porto Alegre: Mercado Aberto, 1984.

GORENDER, J. O escravismo colonial. 4. ed. São Paulo: Ática, 1985.

KORNIJESUK, N. A Guerra de Canudos e suas verdades. 31 ago. 2012. Disponível em: <http://guerradecanudos1896.blogspot.com.br/>. Acesso em: 5 nov. 2016.

MUNANGA, K.; GOMES, N. L. O negro no Brasil de hoje. 2. ed. São Paulo: Global, 2016.

PINSKY, J. A escravidão no Brasil. 16. ed. São Paulo: Contexto, 1998.

QUIJANO, A. Colonialidade do poder, eurocentrismo e América Latina. In: LANDER, Eduardo (Org.). A colonialidade do saber eurocentrismo e ciências sociais: perspectivas latino-americanas. Buenos Aires, Argentina: CLACSO, set. 2005. p. 227-278. (Colección Sur Sur).

RAMOS, A. As culturas negras no novo mundo. 3. ed. São Paulo: Editora Nacional, 1979.

RAMOS, W. R. A representação dos negros na Guerra do Contestado no museu paranaense. Trabalho apresentado no XV Encontro Regional de História: 100 anos da Guerra do Contestado, Curitiba, 26 a 29 de julho de 2016. Disponível em: $<$ http://www.encontro2016.pr.anpuh.org/resources/anais/45/1467942565_ARQUIVO _artigoanpuhRenewRamos.pdf>. Acesso em: 12 dez. 2016.

SAES, D. A formação do estado burguês (1888-1891). Rio de Janeiro: Paz e Terra, 1985.

SCALBERT, J. As três idades. Disponível em: <http://www.allposters.com.br/sp/The-Three-Ages-posters_i4044753_.htm>. Acesso em: 15 dez. 2016.

TAVARES, M. História, Memória e esquecimento: identidades silenciadas. In: BAPTISTA, Ana Maria Haddad; TAVARES, Manuel. Culturas, identidades e narrativas. São Paulo: Big Time, 2014. p. 73-113. 